the many biochemical changes which may take place in a yeast cell. It can be strongly recommended.

D. J. Manners

\section{MUSCLE MEETING}

\section{Symposium on Muscle}

Edited by E. Ernst and F. E. Straub. (Symposia Biologica Hungarica, Vol. 8.) Pp. 259. (Akademiai Kiado: Budapest, 1968.) 100s.

Tris book contains the proceedings of the symposium on muscle held in Budapest, which was attended by seventy-seven participants. It is unfortunate that publication of such a book takes so long, the actual date of the symposium being September 1966. Such a delay means that most of the material formally presented at the meeting has already appeared in journals, though possibly the representation occasionally clarifies an author's meaning. The main advantage in publishing such a volume, however, can often be found in the discussions, and these are well in evidence in the present book.

The book falls into several sections, including structural aspects of striated muscle, structural proteins and their interaction, organic substances of striated muscle, univalent ions and heart muscle, mechanical activity of striated muscle as well as energetic aspects of muscular contraction. Each section begins with a full length formal paper by a recognized authority, which is followed by shorter presentations and discussions. The length of the shorter papers and the amount of (reported) discussion vary from topic to topic. For example, some thirtyseven pages follow the major contribution on "Mechanical Activity of Striated Muscle" (led by F. F. Jobis) while only nine follow "Energetic Aspects of Muscular Contraction" (led by D. R. Wilkie). Such differences prevent the book from presenting a balanced review of the present knowledge of the form and function of skeletal muscle, but after all such was not the intention. This volume will find its rightful place on library shelves from which it will rightly be taken down from time to time for a rereading of some point discussed in Budapest. For the main data the authors are probably best read in the original.

A. J. Buller

\section{PERMEABILITY OF MEMBRANES}

\section{Cellular Aspects of Membrane Permeability}

By E. Schoffeniels. (International Series of Monographs in Pure and Applied Biology. Division: Modern Trends in Physiological Seiences, Vol. 28.) Pp. xiii + 266. (Pergamon: Oxford, London and New York, 1967.) 100s.; $\$ 15$.

DR SChOFFenIEL's monograph is divided into three parts. The first part covers familiar ground, dealing with ion distribution between cells and tissue fluid, ion fluxes across cellular membranes, active transport, membrane potentials, membrane ATPases, and the effect of hormones and alkaline earth cations on membrane permeability. The coverage is full and many useful tables of data are included. Quantitative physico-chemical explanations are, however, inadequate and equations are frequently simply quoted without attempt at derivation. The second part deals with the operation of the mechanisms described in the first part, in various spocific tissues and specific animal groups, particularly amphibian skin and excitable mombranes. There are also useful chapters on the role of nitrogenous substaneos in osmoregulation in certain animals and on the nervous control of membrane permeability. The third and shortest section deals with the fundamental structure and chemical composition of membranes including electronmicrographs and phospho- lipid analyses of membranes. This materia] might with advantage have been placed carlier in the book. In this section some functional evidence bearing on the possible existence of membrane pores is also discussed.

While such a wide presentation of information com. mands respect, there are some serious weaknesses in this book. First, knowledge of the physico-chemical back. ground essential for understanding membrane phenomena has, in the main, been assumed so that non-specialist readers may run into difficulty. Second, there are some serious omissions. Mention of cation selective electrodes is confined to a footnote on page 194 and a reference to Eisenman (1962). The work of Hinke, Lev and Kostyuk is not mentioned. The important studies of Thompson, Haydon, Mueller and Rudin and others on artificial bimolecular phospholipid membranes and their remarkable resemblance to living membranes have also been overlooked. Third, the majority of the references are somewhat out of date. For example, the latest reference to Keynes is in 1957. There is an impression that this book could and should have been produced two or three years ago. Some minor criticisms include the lavish provision of eleven coloured plates of ordinary histological preparations of respiratory epithelia. Their contribution to the text seems disproportionate to the large increase which they must have made in the cost of this already expensive book. There are a number of misprints-for example, the lettering of Figs. 2.5 and 2.6-and the index is inadequate.

In spite of its weaknesses, specialists in this field must be grateful to Dr Schoffeniels for a useful assembly of information especially in relation to his own work on amphibian skin.

D. A. 'T. DICK

\section{RADIOSTERILIZATION}

\section{Radiosterilization of Medical Products and Recom- mended Code of Practice}

(Proceedings of the Symposium held by the International Atomic Energy Agency at Budapest, June 5-9, 1967, and Results of a Panel Meeting held by the International Atomic Energy Agency at Vienna, December 5-9, 1966. Proceedings Series.) Pp. 458. (International Atomic Energy Agency: Vienna; HMSO: London, 1967.) 246 schillings; $67 s$.; $\$ 9.50$.

THE radiosterilization of disposable hypodermic syringes and catgut is now a well established commercial process and this report is of an international symposium held to examine the possibility of extending the field of this type of cold sterilization.

The report comprises a comprehensive introductory review of radiosterilization and papers on its use with pharmaceuticals and bioproducts (12 papers), biological tissues (6), vaceines (5), medical devices (4), the radiosensitivity of microorganisms (4), technical and economic aspects (6), and it also contains a suggested code of practice for manufacturers using radiosterilization. Each paper is in its original language (29 English, 5 French, 4 Russian and 1 Spanish) and each has an abstract in English. A full account of the discussion after each paper is given in English.

The symposium does not answer the question "What is a sterilizing dose of radiation?" although more authors recognizo $2.5 \mathrm{M}$ rad as being satisfactory than those demanding $4.5 \mathrm{M}$ rad. (An unfortunate typographical error on page 217 reports some bacteria as being capable of withstanding $200 \mathrm{M}$ rad.) The overall conclusion to be drawn from the symposium is that the sterilizing doso deponds on several factors including initial contamination of the item to be sterilized, the genus and species of organism present, its immediate environment, and so on. Pandula et al. (page 83) report that the decomposition of some pharmaceuticals was dose rate dependent even in the 